\title{
İntragastrik Obezite Balonu’nun Karanlık Yollarda Gizemli Kayboluşu: İki Olgu ve Literatürün Gözden Geçirilmesi
}

\author{
Intragastric Obesity Balloon's Mysterious Vanishing in the Dark Alleys: Two Cases and Review \\ of the Literature
}

Sezgin BARUTCU, Abdullah Emre YILDIRIM, Bugra Tolga KONDUK

Division of Gastroenterology, Faculty of Medicine, University of Gaziantep, Gaziantep, Turkey.

\section{Özet}

Obezite ile ilişkili morbidite ve mortalite Hipokrat döneminden beri bilinmektedir. Obezite dünya çapında salgın boyutuna ulaşmış ve son zamanlarda daha ciddi bir tıbbi, sosyal ve ekonomik sorun haline gelmiştir. Yaşam tarzı değiş̧ikliği ve farmakoterapinin sınırlı bir yararı vardır. Bariatrik cerrahi, uzun süreli kilo azaltmanın etkili bir yöntemi olup aşıı kilonun yaşamı tehdit eden komplikasyonlarını da azaltmaktadır. Daha az invaziv, daha güvenli ve daha ucuz endoskopik tedaviler cerrahiye alternatif olabilir. İntragastrik obezite balonu, bu amaçla dünya çapında uygulanan popüler bir yöntemdir. Patlamış balonun yer değiştirmesine bağlı bağırsak tıkanıklığı, bu prosedürün nadir fakat hayatı tehdit eden bir komplikasyonudur.

Anahtar Kelimeler: Sönmüş balon, İntragastrik balon komplikasyonu, Luminal obezite tedavisi

\begin{abstract}
The morbidity and mortality associated with obesity have been known since the time of Hippocrates. Obesity has reached epidemic proportions worldwide and becomes a more serious medical, social, and economic problem recently. Lifestyle modification and pharmacotherapy have limited benefit. Bariatric surgery is an effective method of durable weight reduction with risks of life treating complications. Less invasive, safer and cheaper endoscopic therapies may be an alternative to surgery. The intragastric obesity balloon is a popular tool performed worldwide Intestinal obstruction due to migration of deflated balloon is a rare but life-threatening complication of this procedure.
\end{abstract}

Key words: Deflated balloon, Luminal obesity treatment, Intragastric balloon complication

Yazışma Adresi: Sezgin BARUTÇU, Gaziantep Üniversitesi Tıp Fakültesi Gastroenteroloji BD, Gaziantep, Türkiye, Telefon: 0342 3416689, Mail: sezginbarutcu@hotmail.com

ORCID No(Sirasıyla): 0000-0003-0823-3215, 0000-0002-4386-9297, 0000-0002-9138-9984

Geliş tarihi: 22.05 .2020

Kabul tarihi: 08.07 .2020

DOI: Doi: $10.17517 \mathrm{ksutfd} .741480$ 


\section{INTRODUCTION}

Obesity is becoming more prevalent cause of chronic health problems including impaired quality of life, decreased life expectancy, and increased financial pressure on healthcare systems throughout the world. The prevalence of obesity has increased dramatically over the past thirty years, and is now approaching 35\% in men and $40 \%$ in women.(1) Many strategies have been developed to promote weight loss including lifestyle modifications, medications, and restrictive and/or malabsorptive surgical techniques; however a few of them are effective and permanent. Intragastric balloons (IGB) are temporary, reversible, free-floating, space-occupying devices which are placed endoscopically into the stomach and inflated either with air or more commonly with saline to decrease the free volume of stomach and provide an early satiety sensation which are used mainly to obtain initial weight reduction in the super-obese patients prior to bariatric surgery and in morbidly obese patients who are not fit for surgery (2). Also IGB therapy may fill the gap between weight loss drugs and surgery. However, most of the patients can safely lose weight without complications or with minimal complications with this treatment method (3). Although it is a safe method, many complications related to IGB can be seen. These are obstruction due to the movement of the IGB, gastroesophageal reflux with severe esophagitis and upper gastro-intestinal bleeding, especially during balloon insertion or removal (4). Intestinal obstruction due to migration of deflated balloon is a rare but life-threatening complication of the procedure. Here we present two cases of spontaneous Heliosphere ${ }^{\varpi}$ intragastric obesity balloons' (Helioscopie, Vienne, France) deflation and pass gastrointestinal tract without major complication.

\section{CASE-1}

A 46-year-old woman was admitted to our obesity clinic with complaints of weight regain after placement of IB. According to our records, an air-filled Heliosphere Bag ${ }^{\circledast}$ Intragastric Balloon (HIB) had been introduced in her stomach for morbid obesity 11 months ago. HIB is a device which has $720 \mathrm{~cm}^{3}$ of volume, $11 \mathrm{~cm}$ in diameter and less than 30 grams in weight. Tolerance was very good, limited only to some dyspeptic symptoms during the first day after insertion. She initially had lost a significant amount of weight after the procedure, exactly 26 kilograms, for the first six months which lead to a decline of $8.57 \mathrm{~kg} / \mathrm{m}^{2}$ in body mass index detected during routine control. The abdominal $\mathrm{x}$-ray control after procedure showed the presence of the HIB in her stomach. We recommended that HIB should have been removed approximately six months after the placement because of the risk of spontaneous balloon deflation which may have resulted in migration. Despite all warnings she had postpo- ned HIB removal because of continuing to lose weight. At the 11th month of the procedure, she was admitted to outpatient clinic, complained that weight loss had stopped, and on the contrary she started to gain weight in the last month. In this period no complaints indicating intestinal obstruction were exist. Her past medical history was significant only for diabetes mellitus controlled with oral anti diabetics, and psychiatric disorder with anxiety.

She underwent an esophagogastroduodenoscopy (EGD) with intention to remove the HIP. However at the time of the EGD, it was noted that the HIB was no longer present. An urgent abdominal X-ray also did not show the HIB. Computed tomography of the abdomen was performed to determine the location of the HIB and abdomen Computed tomography was normal. Endoscopic and radiological findings suggested that the balloon had passed through the gastrointestinal tract by natural ways in the stool without causing any complaints. Interestingly the patient was not aware of this incident and she complained only for intermittent constipation.

\section{CASE-2}

A 36-year-old woman was admitted to our outpatient clinic to obtain information about endoscopic therapies for obesity. She had no history of chronic diseases and surgery. She also had tried lifestyle modifications and diets for a couple of times but she could not lose weight. On admission, her body mass index was nearly $39 \mathrm{~kg} / \mathrm{m}^{2}$ and her upper gastrointestinal endoscopy was totally normal. After initial assessment, HIB was introduced in stomach. HIB inflated to $600 \mathrm{~cm}^{3}$ of volume, and $10 \mathrm{~cm}$ in diameter. In the following week abdominal $\mathrm{x}$-ray control showed that the inflated balloon was intact in the stomach, and we had planned to remove balloon six months after as recommended by the manufacturer. After the first week, patient continued to come to clinic controls monthly. In the first three months, she lost 13 kilograms. After the first three months, weight loss slowed down to two kilograms monthly and the patient was lost to follow-up. At the 8th month of procedure she admitted to our clinic to have her balloon removed. She told us that her weight loss stopped after 5 months, she has been regaining weight since then, and had no complaints except for weight gain. She underwent EGD with intention to remove the HIB but as in first patient the balloon was not detected in the stomach. An urgent abdominal CT was performed but again the balloon was not detected. Hence, we thought that the balloon had passed through the gastrointestinal tract without causing complaints. Similar to the first case, this patient also had not noticed the balloon in her stool.

The changes of body mass index and weights of both patients during the follow-up period were summarized in Figure 1. 


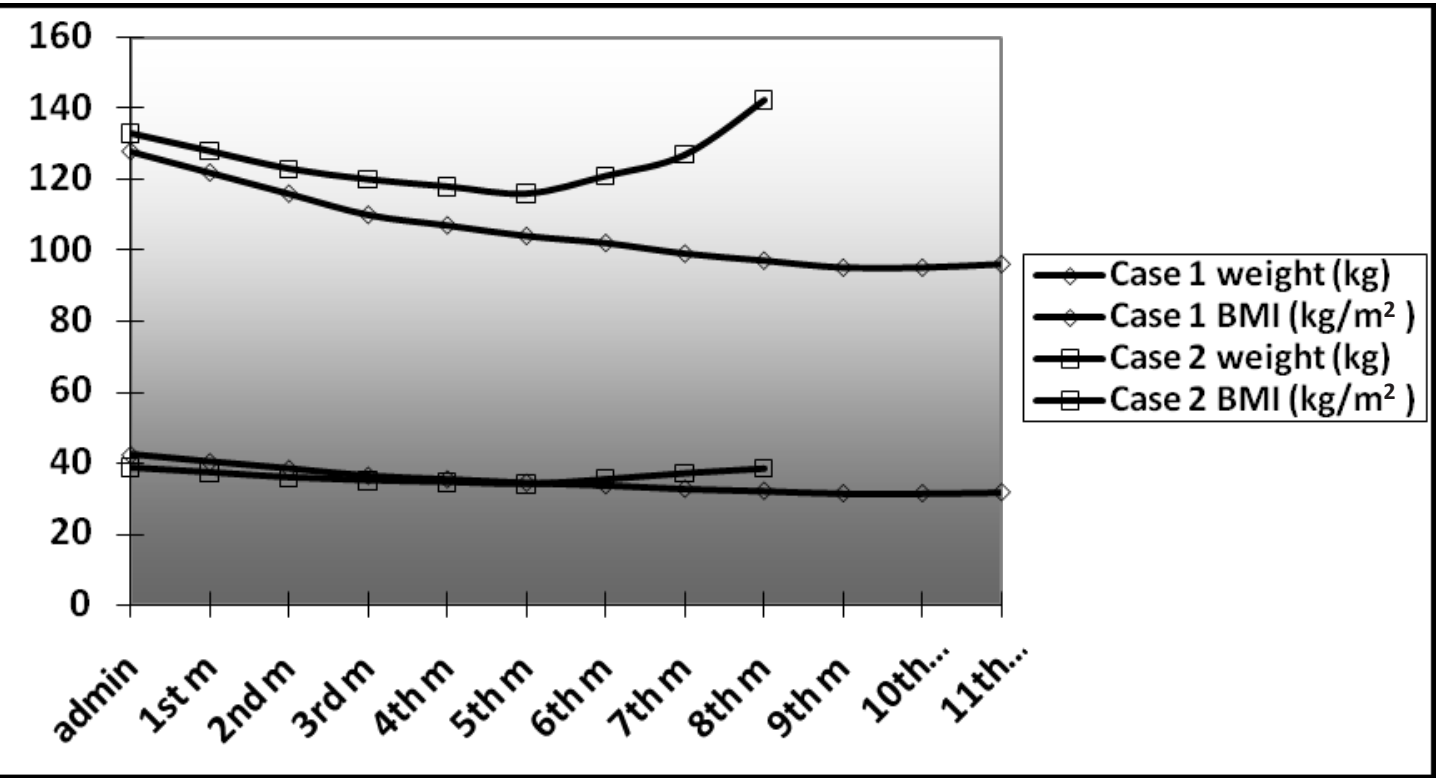

Figure 1. The changes of body mass index and weights of both patients during the follow-up period

Table 1. Advantages and disadvantages of most used two type balloons in worldwide.

\begin{tabular}{|l|l|l|}
\hline \multirow{2}{*}{ Advantage } & Heliosphere ${ }^{\circledR}$ Bag balloon & BIB $\AA$ balloon \\
\hline Disadvantage & Weights only 30gr (lighter) & Very low complication rate \\
\hline & Better tolerance in early period & Easy removal \\
\hline & Spontaneous partial deflation rate high & Heavier (700gr) \\
\hline & Difficult removal & Digestive intolerance \\
\hline & Absence of leakage marker (methylene blue) & Early removal requirements \\
\hline & About 45\% more expensive in Turkey & \\
\hline
\end{tabular}

\section{DISCUSSION}

Bariatric surgical procedures are the most effective and enduring treatment for morbid obesity but are associated significant complications. Operative therapies are not suitable for all obese patients or are not well accepted by all operation candidates. There is a growing need for less-invasive procedures as effective as surgery. A less invasive endoluminal method for the treatment of obesity, namely intragastric obesity balloons, can be an option for this group of patients. Endoscopic IGB can be performed for obese patients who reject bariatric surgery, morbidly obese (BMI $>40)$, superobese patients $(\mathrm{BMI}>50)$ in preparation for bariatric operations and patients with BMI between 30 and 35 with other comorbidities $(5,6)$

The first air-filled balloons placed intragastrically for weight loss were introduced in the 1980s. Early devices
(Garren-Edwards, Ballobes, Taylor and Wilson-Cook balloons) had sharp edges and because of structural and placement difficulties, they had excessive failure and complication rates (7). In recent years a silicone saline-filled balloon "BioEnterics intragastric balloon $\left(\mathrm{BIB}^{\circledast}\right)$ " and a new air-filled intragastric balloon, the HIB was introduced, respectively. More recent models of the intragastric balloons have demonstrated a very low complication rate, and satisfactory outcomes as a result of better design, endoscopic insertion under direct vision, and easy removability (8). These devices follow the proposed criteria for ideal intragastric balloons while they have their own advantages and disadvantages (Table 1). Both of them seem to achieve good results concerning weight loss although some worrisome data about their safety has been reported in case reports. 
Reported complications include esophagitis, esophageal erosions, gastroesophageal reflux, nausea, vomiting, abdominal discomfort, dehydration, hypokalemia, peptic ulcers, gastric perforation, balloon rupture and gastric obstruction. Approximately $7 \%$ of patients are intolerant to IB. In a large case series and a meta-analysis complication rates are reported as follows; esophagitis (1.27\%), gastric perforation $(0.21 \%)$, gastric outlet obstruction $(0.76 \%)$, gastric ulcer (0.2\%), balloon rupture $(0.36 \%)$ and death $(0.07 \%)(9,10)$.

Significant complications connected with IB implantation such as intestinal obstruction, and perforation are rarely observed $0.2 \%$ (11). Over the years, many intestinal obstruction cases due to spontaneous deflation with migration of the balloon into the small bowel were reported in the literature (12).

The common presenting symptoms of these cases are crampy abdominal pain, nausea, and acute onset vomiting. In a case of migration several ways would be followed; observation till to evacuation of the balloon, endoscopic removal or surgical interventions. Intestinal obstruction risk is significantly higher when balloons are left in place longer than the recommended period (13). In the majority of cases, patients were inserted with BIB. Only few HIB cases were reported which caused intestinal obstruction and require surgical enterostomy under laparotomy or laparoscopy (14). In literature search, at the time of removal HIB were not found in the stomach in three cases, and as our patients abdominal $\mathrm{x}$-rays and CT scan were negative. It was concluded that they had passed in the stool without causing any complaints and clinical findings as in our case $(8,15)$.

Intestinal obstruction and perforation requiring surgery are extremely rare complications of IB. Complications reported in the literature with BIB are more than with other balloons. The reason for why complications requiring surgery are reported more may be explained by the longstanding usage of BIB. It has been suggested as the experience with HIB increased over years, high spontaneous partial deflation rate is a disadvantage, and important risk for migration. This fact indicates that the HIB probably has inadequate resistance to acidity. Despite this overt disadvantage, the good news is that self-deflations without migration which may lead to surgical intervention rarely occur. HIB has a double-layer structure with a polyurethane reservoir, and an external silicone envelope. Thus self-deflated balloon cannot migrate beyond the pylorus. This would be the possible mechanism.

Patients with self-deflated balloon may not always be as lucky as our cases. Risk of migration, intestinal obstruction, and life-threatening complications always could exist. Unlike $\mathrm{BIB}, \mathrm{HIB}$ does not have a leakage marker such as methylene blue, thus self deflation may not be recognized instantaneously. Nevertheless, during follow-up weight regain may be a clue for partial self-deflation, and early intervention may prevent life-threatening complications.

Conflicts of Interest Statement: None of the authors had any financal or personel relationhips with other indivi- duals or organizations that might inappropriately influence their work during the submission process.

Research Contribution Rate Statement Summary: The authors declare that, they have contributed equally to the manuscript.

\section{REFERENCES}

1. Flegal KM, Kruszon-Moran D, Carroll MD, Fryar CD, Ogden CL. Trends in Obesity Among Adults in the United States, 2005 to 2014. JAMA 2016; 315: 2284-2291

2. Farina MG, Baratta R, Nigro A, Vinciguerra F, Puglisi C, Schembri $\mathrm{R}$ et al. Intragastric balloon in association with lifestyle and/or pharmacotherapy in the long-term management of obesity. Obes Surg. 2012; 22: 565-71.

3. Abeid M, Kaddah T, Zaitoun NA, Alsamman MA. Efficacy and Safety of Intragastric Balloon Placements in 1600 Case, an Experience from the Middle East. Obes Surg. 2019;29(7):20872091.

4. Abou Hussein BM, Khammas AA, Al Ani AM, Swaleh AH, Al Awadhi SA, El Tayyeb YH et al. Gastric Perforation following Intragastric Balloon Insertion: Combined Endoscopic and Laparoscopic Approach for Management: Case Series and Review of Literature. Obes Surg 2016;26:1127-32.

5. Velotti N, Bianco P, Bocchetti A, Milone M, Manzolillo D, Maietta $\mathrm{P}$ et al. Acute complications following endoscopic intragastric balloon insertion for treatment of morbid obesity in elderly patients. A single center experience. Minerva Chir. 2020;75(2):72-76.

6. Doldi SB, Micheletto G, Perrini MN, Rapetti R. Intragastric balloon: another option for treatment of obesity and morbid obesity. Hepatogastroenterology 2004;51:294-7

7. Hogan RB, Johnston JH, Long BW, Sones JQ, Hinton LA, Bunge $J$ et al. A double blind, randomised, sham controlled trial of the gastric bubble for obesity. Gastrointest Endosc. 1989; 35: 381-5.

8. De Castro ML, Morales MJ, Del Campo V, Pineda JR, Pena E, Sierra JM et al. Efficacy, safety, and tolerance of two types of intragastric balloons placed in obese subjects: a double-blind comparative study. Obes Surg. 2010; 20: 1642-6.

9. Genco A, Bruni T, Doldi SB, Forestieri P, M Marino M, Busetto $\mathrm{L}$ et al. Bioenterics intragastric balloon: the Italian experience with 2515 patients. Obes Surg. 2005;15:1161-4.

10. Dumonceau JM. Evidence-based review of the Bioenterics intragastric balloon for weight loss. Obes Surg. 2008;18:1611-7.

11. Dąbrowiecki S, Szczęsny W, Popławski C, Sosnowski D. Intragastric Balloon (BIB system) in the treatment of obesity and preparation of patients for surgery-own experience and literature review. Pol Przegl Chir. 2011;83:181-7.

12. Hegade VS, Sood R, Douds AC. Small bowel obstruction induced by spontaneous partial deflation of an intragastric balloon. Ann R Coll Surg Engl. 2012; 94:171-3.

13. Stavrou G, Tsaousi G, Kotzampassi K. Life-threatening visceral complications after intragastric balloon insertion: Is the device, the patient or the doctor to blame? Endosc Int Open. 2019;7(2):122-129.

14. Drozdowski R, Wyleżoł M, Frączek M, Hevelke P, Giaro M, Sobański P. Small bowel necrosis as a consequence of spontaneous deflation and migration of an air-filled intragastric balloon-a potentially life-threatening complication. Wideochir Inne Tech Malo Inwazyjne.2014;9:292-6.

15. Forestieri P, De Palma GD, Formato A, Giuliano ME, Monda A, Pilone $\mathrm{V}$ et al. Heliosphere Bag in the treatment of severe obesity: preliminary experience. Obes Surg. 2006;16:635-7. 